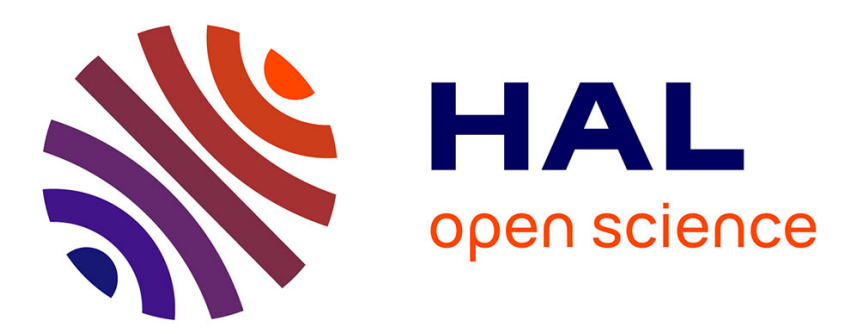

\title{
Emerging economic viability of grid defection in a northern climate using solar hybrid systems
}

Abhilash Kantamneni, Richelle Winkler, Lucia Gauchia, Joshua Pearce

\section{To cite this version:}

Abhilash Kantamneni, Richelle Winkler, Lucia Gauchia, Joshua Pearce. Emerging economic viability of grid defection in a northern climate using solar hybrid systems. Energy Policy, 2016, 95, pp.378-389. 10.1016/j.enpol.2016.05.013 . hal-02113508

\section{HAL Id: hal-02113508 \\ https://hal.science/hal-02113508}

Submitted on 28 Apr 2019

HAL is a multi-disciplinary open access archive for the deposit and dissemination of scientific research documents, whether they are published or not. The documents may come from teaching and research institutions in France or abroad, or from public or private research centers.
L'archive ouverte pluridisciplinaire HAL, est destinée au dépôt et à la diffusion de documents scientifiques de niveau recherche, publiés ou non, émanant des établissements d'enseignement et de recherche français ou étrangers, des laboratoires publics ou privés. 
Preprint: Abhilash Kantamneni, Richelle Winkler, Lucia Gauchia, Joshua M. Pearce, Emerging economic viability of grid defection in a northern climate using solar hybrid systems. Energy Policy 95, 378-389 (2016). doi: 10.1016/j.enpol.2016.05.013

\title{
Emerging Economic Viability of Grid Defection in a Northern Climate Using Solar Hybrid Systems
}

Abhilash Kantamneni ${ }^{1}$, Richelle Winkler ${ }^{2}$, Lucia Gauchia ${ }^{3,4}$, Joshua M. Pearce, ${ }^{3,5, *}$

1. Department of Computer Science, Michigan Technological University, Houghton, MI, USA

2. Department of Social Sciences, Michigan Technological University, Houghton, MI,USA

3. Department of Electrical \& Computer Engineering, Michigan Technological University, Houghton, MI, USA

4. Department of Mechanical Engineering-Engineering Mechanics, Michigan Technological University Houghton, MI, USA

5. Department of Materials Science \& Engineering, Michigan Technological University, Houghton, MI, USA

* Corresponding author: 1400 Townsend Drive, Houghton, MI 49931-1295 pearce@mtu.edu

\begin{abstract}
High demand for photovoltaic (PV), battery, and small-scale combined heat and power (CHP) technologies are driving a virtuous cycle of technological improvements and cost reductions in off-grid electric systems that increasingly compete with the grid market. Using a case study in the Upper Peninsula of Michigan, this paper quantifies the economic viability of off-grid PV+battery+CHP adoption and evaluates potential implications for grid-based utility models. The analysis shows that already some households could save money by switching to a solar hybrid off-grid system in comparison to the effective electric rates they are currently paying. Across the region by 2020, 92\% of seasonal households and $\sim 75 \%$ of year-round households are projected to meet electricity demands with lower costs. Furthermore, $\sim 65 \%$ of all Upper Peninsula single-family owner-occupied households will both meet grid parity and be able to afford the systems by 2020. The results imply that economic circumstances could spur a positive feedback loop whereby grid electricity prices continue to rise and increasing numbers of customers choose alternatives (sometimes referred to as a "utility death spiral"), particularly in areas with relatively high electric utility rates. Utility companies and policy makers must take the potential for grid defection seriously when evaluating energy supply strategies.
\end{abstract}

Keywords: energy policy; electric utility; photovoltaic; distributed generation; off-grid; solar energy

\section{Introduction}

Both the global and U.S. solar photovoltaic (PV) industries have been growing rapidly (SEIA, 2013) as technical improvements and scaling have significantly reduced PV module costs and public support of solar energy has led to favorable policies in many regions (Branker and Pearce, 2010; SEIA, 2011; BNEF, 2012; IREC, 2012; Feldman, 2014; SEIA,2014). PV technology converts sunlight to highexergy electricity reliably, safely, sustainably (Pearce, 2002; Prindle et al., 2007; Timilsina et al., 2012; Pathak et al., 2014) and now economically (Branker, et al., 2011; Bazilian et al., 2013). High demand for new PV projects is expected to continue, driving a virtuous cycle of PV-related cost reductions (McDonald \& Schrattenholzer, 2001; van der Zwaan \& Rabl, 2003; Watanabe, et al., 2003; Nemet, 2006; Candelise et al., 2013; Barbose et al., 2014). Already the solar levelized cost of electricity (LCOE), which the average total cost to build and operate a power-generating asset over its lifetime divided by the total energy output of the asset over that lifetime, from small-distributed on-grid PV systems is competitive with utility electrical rates throughout some regions in the U.S. (Branker et al., 2011; Breyer and Gerlach, 2013; Reichelstein and Yorston, 2013). On the other hand, utility electrical prices are expected to continue to climb from a combination of: i) aging infrastructure (Brown \& Willis, 2006; Li \& Guo, 2006; Willis \& Schrieber, 2013); ii) increased regulation (Pudasainee, et al., 2009; Celebi, et al., 2012; Rallo, et al., 2012; Gerrard and Felton, 2014); iii) resource scarcity [ability to extract fuels such as coal at a given investment] (De Cian et al., 2013; Kriegler, et al., 2013; Murphy, et al., 2014); and iv) potential liability 
Preprint: Abhilash Kantamneni, Richelle Winkler, Lucia Gauchia, Joshua M. Pearce, Emerging economic viability of grid defection in a northern climate using solar hybrid systems. Energy Policy 95, 378-389 (2016). doi: 10.1016/j.enpol.2016.05.013

from conventional pollution and now carbon-dioxide $\left(\mathrm{CO}_{2}\right)$ emissions being regulated as greenhouse gas pollution (Wilson, 2007; Burtraw, 2013; Pratson, 2013; Linn, 2014; Burtraw 2014). For these reasons, solar PV represents a threat to the conventional electric utility model.

An even greater threat is the coupling of PV to storage technologies, as batteries have also been advancing rapidly (Agnew and Dargusch, 2015). The dominant battery technology utilizes lithium-ion (Li-ion) due to its higher energy density $(700 \mathrm{Wh} / \mathrm{l})$. However, theoretical energy densities point to future improvements with nanostructures and new materials using abundant materials such as lithium-sulfur (LiS) $(2600 \mathrm{Wh} / \mathrm{kg})$ and lithium-air (Li-air) $(11,000 \mathrm{Wh} / \mathrm{kg})$ technologies (Amine, et al., 2014). Along with these technological advancements, battery costs are dropping, with current costs being between $\$ 600$ $1,000 / \mathrm{kWh}$. The expectations are to reach $\$ 225 / \mathrm{kWh}$ in 2020 and to further drop below $\$ 150 / \mathrm{kWh}$ in the longer term (U.S. DOE, 2013). Economies of scale will also factor into future battery prices, especially with Tesla's increased battery manufacturing plans through its GigaFactory, which plans to produce 500,000 batteries a year starting 2017 (Tesla, 2014). Battery packs (Power Wall) currently retail for $\$ 350 / \mathrm{kWh}$ for home use (Tesla, 2015). These developments have led to the potential for battery+PV levelized cost of electricity (LCOE) being less expensive than grid electricity, which could promote largescale grid defection (Rocky Mountain Institute, 2014).

Recent analysis on grid defection (Rocky Mountain Institute, 2014) investigated state-level markets of special cases (New York, Kentucky, Texas, California and Hawaii) and found that grid parity of solar hybrid systems has already been achieved in some places (notably throughout most of Hawaii) and is imminent in several markets for tens of millions of customers in the United States by 2020. Grid parity occurs when an alternative energy source can generate power at a LCOE that is less than or equal to the price of purchasing power from the electricity grid. However, many regions in the U.S. (e.g. northern areas with limited solar potential and high heating demand during cold winter months) cannot have off-grid PV systems without prohibitively large battery systems. Small-scale combined heat and power (CHP) systems, which produce electricity as well as thermal energy that can be used for home heating, provide a potential solution for off-grid power backup of residential-scale PV + battery arrays CHP systems fueled by natural gas can be used to offset thermal loads from a conventional heating system while meeting household electric loads. CHP systems can be effective in recapturing waste heat that would normally be lost from the electricity generation process, while also minimizing emissions from conventional sources (Nosrat et al., 2014; Shah, et al., 2015).

This paper investigates the potential for PV+battery+CHP systems to reach grid parity in the Upper Peninsula of Michigan (UP) - a mostly rural, remote region of the northern United States with a relatively low-income population. An analysis is performed from an economic standpoint using existing technologies, to determine if off-grid solar+battery+CHP systems can produce electricity at lower costs to consumers than that provided by conventional grid-tied electricity. The analysis integrates differential demand by household size and for seasonal and full-year residents in sizing systems and in estimating costs. The work extends prior research on grid parity by showing that even in unlikely places with low solar potential, such as the UP, design configurations are already becoming viable that make off-grid hybrid solar systems technologically and economically feasible.

Second, this study considers the economic viability of off-grid solar hybrid systems in a low income region. Even if grid parity is achieved, if households cannot afford the installment costs, then defecting from the grid is not economically feasible. The analysis considers households' financial ability to invest in solar hybrid systems based on income levels and access to funding. If economically viable systems are possible in this case region, with long cloudy winters and low solar penetration and a low income population, it would suggest that off-grid solar hybrid systems would be feasible alternatives for households across much of the United States. 
Preprint: Abhilash Kantamneni, Richelle Winkler, Lucia Gauchia, Joshua M. Pearce, Emerging economic viability of grid defection in a northern climate using solar hybrid systems. Energy Policy 95, 378-389 (2016). doi: 10.1016/j.enpol.2016.05.013

\section{Methods of Analysis}

This study models the point at which the financial costs of PV+battery+CHP systems reach grid parity for single-family homeowners, using the Upper Peninsula (UP) of Michigan as a case study. The goal is to estimate the number and proportion of homeowners in the UP for whom it is economically feasible to invest in off-grid solar hybrid systems. The analysis is restricted to single-family owneroccupied homes (including seasonal and year-round residents), because residents of these types of housing units have more control and personal incentive for investing in energy infrastructure for their home than do renters. There are four key steps to the analysis: (1) estimate electric consumption for UP households by size and type; (2) design generalized solar hybrid systems to meet those consumption needs; (3) model future solar-hybrid system prices and grid-based utility rates to determine the economic viability of grid defection for homeowners with various consumption levels; and finally (4) match demographic data to estimate the number and proportion of homeowners that are and will be in an economic position to defect given economic competitiveness of solar, based on their electric consumption and household income.

\subsection{The Upper Peninsula of Michigan Case}

The Upper Peninsula (UP) is situated between Lake Superior (along its northern border) and Wisconsin, Lake Michigan, and Lake Huron to the south. Altogether, it stretches about 320 miles from east to west and encompasses about 29\% of Michigan's land area, but has only about 3\% of its total population (US Census, 2010). At Census 2010, the UP was home to 311,361 residents and had a population density of just 19 people per square mile. There are no metropolitan counties within the UP, with the closest being Green Bay, Wisconsin, Duluth, MN, or Sault Saint Marie, Canada. Historically developed in association with mining and timber industries, today the land is heavily forested and the current economy is driven primarily by education, tourism, services, and government.

In many ways, the UP is fairly typical of a remote and rural location with scenic natural areas and abundant outdoor recreation. About $24 \%$ of all housing units are for seasonal, recreational or occasional use (US Census, 2010). This is similar to the proportion of seasonal homes in other rural natural amenity destinations, including the northwoods areas of the Upper Midwest, mountainous areas of the US west, and rural areas of northern New England. Among permanent residents, incomes are relatively low (median household income is about $77 \%$ of United States total). Poverty rates (15.4\% compared to US at $14.9 \%$ ) and unemployment rates (10.5\% compared to US at 9.3\%) are relatively high (ACS 2008-2012). The area experiences long, cold winters with some of the heaviest snowfalls in the United States and short, relatively cool summers with average-high August temperatures of $22^{\circ} \mathrm{C}$, resulting in little demand for air conditioning. Because of its northern latitude, daylight hours are short in the winter and long in the summer. In total, the climate is such that residential electric demand is heating season dominated, with approximately 324 heating degree days per year (National Climatic Data Center, 2001).

Several investor-owner, cooperative, and municipal electric utilities have service agreements in the region (see Figure 1 and Table 1). Together, they service about 155,000 residential customers. Figure 1 shows service area boundaries across the UP, as attributed in this study. County subdivisions are the basic unit of analysis used for demographic data and they must be assigned to a particular utility service area, in order to associate rates to households. Because service areas do not always follow political units, subdivisions with more than one provider are attributed to the most dominant provider in this map and throughout the analysis.

Insert Figure 1 about here

Effective rates estimate the total cost for a consumer per kilowatt hour (kWh) that is comparable across all utilities by incorporating energy changes, service charges, state-mandated charges, and power supply cost recovery factors. Table 1 and Figure 1 show how these rates vary considerably across providers in the region, ranging from about $\$ 0.10 / \mathrm{kWh}$ for municipally owned utilities (near the US 
Preprint: Abhilash Kantamneni, Richelle Winkler, Lucia Gauchia, Joshua M. Pearce, Emerging economic viability of grid defection in a northern climate using solar hybrid systems. Energy Policy 95, 378-389 (2016). doi: 10.1016/j.enpol.2016.05.013

average) to an effective rate of over $\$ 0.24 / \mathrm{kWh}$ (more than double the US average).

Insert Table 1 about here

\subsection{Estimating Electric Consumption}

The first task is to estimate annual electric consumption in kWh for single-family homeowners in the UP. Because different types of households have different energy demands, consumption is estimated for seasonal vs permanent residents and by household size. Two of the utilities in the service area include reliable data on electric consumption broken down by seasonal and year-round residents-Cloverland and Alger Delta Cooperatives. For these utilities, the data published in their annual ratebooks for 2013 are used to determine the average annual consumption for seasonal and year-round customers, respectively. For the remaining UP utilities, it is assumed that annual electricity consumption is the average observed for Cloverland and Alger Delta seasonal and year-round customers (2,304 kWh/year and 8,335 kWh/year, respectively). Note that electric consumption in the UP is somewhat lower than the US average (10,905 $\mathrm{kWh} /$ year in 2013) (EIA, 2015).

For year-round homeowners, average annual electric use is specified by household size. Using data from the Residential Energy Consumption Survey (RECS) (EIA, 2009), the average consumption ratios for Midwestern households is calculated by household size and these ratios are applied to singlefamily homeowners in the UP. ${ }^{1}$ The ratios indicate how much more or less electric consumption is typical among households of various sizes in comparison to the average household. For instance, the ratio for the average 1-person household is 0.604 indicating that these households use less electricity than average; while the ratio for the average 5-person household is 1.213 indicating greater than average electric use. These consumption ratios are multiplied by the average consumption data taken from utility ratebooks for full-year occupied households described above to generate an estimate of electric consumption for UP utility customers by household size. Table 2 shows the resulting estimates of energy consumption for the various household types.

\subsection{System Design}

Insert Table 2 about here

The second task is to design a solar hybrid system that can meet the electric demand of each household type shown in Table 2. Following the approach taken by Mundada, et al. (2015), a generic offgrid system was designed comprising a PV array, battery bank and CHP. The system designs were not optimized, but only designed to provide for the homeowners' self-sufficiency needs while minimizing system costs.

\subsubsection{PV System}

Net-metered PV customers typically receive credit for excess electricity they feed back into the grid. As a result, PV systems are often sized to produce as much aggregate electricity as possible for the year, without a careful regard to variation in consumption patterns. The potential off-grid customers of interest here have more incentive to seek an optimal design where the system size meets needs throughout the entire year, but does not overproduce. Using commercially available software (PvSyst), the solar flux available in Houghton County, MI (located in the west-central part of the UP) and class 2 TMY3 (typical meteorological year) solar data averaged from 1991-2005 (NREL, 2014), the optimal design was found to be a 30-degree tilt with south facing arrays providing $3.8 \mathrm{kWh} / \mathrm{m}^{2} /$ day.

\footnotetext{
${ }^{1}$ The Residential Energy Consumption Survey (RECS) (EIA, 2009) provides estimates of electric consumption for the Midwest by household size (Table CE4.3). Comparing RECS data across the survey, average consumption for 3person households approximates the overall average consumption for owner-occupied single family housing units. The 3-person household consumption rate is used as a comparison group for calculating consumption ratios comparing various household sizes, such that the 1-person household ratio=1-person average consumption/3-person average consumption $=0.604$. Ratios less than 1.0 indicate less consumption and ratios above 1.0 indicate more consumption, in comparison to the 3-person household.
} 
Preprint: Abhilash Kantamneni, Richelle Winkler, Lucia Gauchia, Joshua M. Pearce, Emerging economic viability of grid defection in a northern climate using solar hybrid systems. Energy Policy 95, 378-389 (2016). doi: 10.1016/j.enpol.2016.05.013

This PV sizing for the off-grid system in our analysis is still somewhat oversized, resulting in unused (41\%) solar electricity during peak production in the summer. However, optimizing the size of solar-hybrid systems has been discussed elsewhere (Pearce, 2009; Nosrat and Pearce, 2011; Nosrat et al., 2013; Nosrat et al., 2014) and is beyond the scope of this paper. The design results in a large fraction (66\%) of annual electric generation through solar. The installed costs of the PV system are modeled as \$3.50/W at current national average installation cost for a residential system (GTM 2015). Looking forward, costs are currently on track to meet the Sunshot Initiative's target of \$1.50/W by 2020 using International Energy Agency forecasts (IEA 2014). The lifetime of PV was taken as 30 years (Branker, et al. 2011).

\subsubsection{Energy Storage}

The battery system was sized to cover half a day of no sun assuming full charge. During the high solar flux months of the year, this battery design allows for an average home to be powered entirely through solar, while also minimizing costs. During the extended winter (in the UP the median $1000 \mathrm{~W} / \mathrm{m}^{2}$ sun hours is $<2$ hours/day for 5 months of the year) the CHP is used to charge the battery, which covers the load. This allows the CHP to run at its maximum efficiency and extends its lifetime by reducing the necessary duty cycle. Dispatch strategies and optimization routines for such an arrangement have been discussed in detail elsewhere (Ashari \& Nayar, 1999; Hrayshat, 2009; Bernal-Agustín \& Dufo-López, 2009; Gupta et al., 2010; Sadeghi \& Ameri, 2012;2014. Battery systems are modeled at current rates of $\$ 621 / \mathrm{kWh}$ (Shahan, 2015) and are on track to reach $\$ 225 / \mathrm{kWh}$ by 2020 using Department of Energy forecasts (DOE, 2013). The lifetime of the battery was assumed to be 10 years (Mundada, et al., 2015).

\subsubsection{CHP System}

A CHP system with an internal combustion engine running on natural gas was chosen primarily for the relatively low capital costs and higher electrical generation efficiency compared to other technologies (Mundada, et al., 2016). The 1kWe CHP costs are modeled at current rates of $\$ 1400 / \mathrm{kW}$ (Mundada, et al., 2016) and a 15 year replacement was factored into the installed cost, which is a conservative assumption as they are normally rated for 40,000 hours (ARPA-E, 2014). In the dispatch strategy, the CHP contribution to electricity production is always minimized, so that the electricity provided by the solar and battery sub-systems is given precedence to minimize both fuel use and greenhouse gas (GHG) emissions (Nosrat and Pearce, 2011; Nosrat, et al., 2013; Shah, et al. 2015). Previous work on such solar hybrid systems shows that the GHG emissions for the hybrid system are substantially below conventional grid GHG emissions in North America (Nosrat, et al., 2013; Nosrat et al., 2014).

\subsection{Simulation Model}

The third step is to run a Matlab v2015b simulation

(https://github.com/akantamn/GridDefection/) to calculate the LCOE of the solar hybrid system based on the methodology described in Branker et al. (2011) and compared to the cost of grid electricity as a function of time. Natural gas costs were modeled at current residential gas prices of \$0.90/Therm (MPSCGas, 2015) and long term natural gas costs were assumed to increase with inflation (2\%). This approach is consistent with Energy Information Administration's projections for residential natural gas rate increases (EIA-AEO, 2015) up to the year 2020.

It is assumed that all homeowners will finance system installation through a non-profit program supported by the Michigan Public Service Commission (Michigan Saves) that provides affordable financing for energy-efficiency and renewable-energy systems. A loan interest rate of $4.99 \%$ was used, based on Michigan Saves (2015) maximum loan interest rate for residents in the Upper Peninsula. Utility rate increases were modeled assuming that average annual rate increases experienced by each utility over 
Preprint: Abhilash Kantamneni, Richelle Winkler, Lucia Gauchia, Joshua M. Pearce, Emerging economic viability of grid defection in a northern climate using solar hybrid systems. Energy Policy 95, 378-389 (2016). doi: 10.1016/j.enpol.2016.05.013

the fifteen year period 2000-2015 (2\%-7\%) will continue each year into the future (MPSC, 2015). This 'business as usual' case likely presents a conservative estimate of near-term utility rate increases. It ignores any potential rate changes associated with the costs of retiring or updating aging coal-fired power plants and building new natural gas fired power plants or building new transmission lines, all of which are under consideration or development in the region in association with meeting Clean Power Plan compliance (NERA, 2014). Table 3 summarizes the cost assumptions, which are all based on current costs and extrapolations of recent historical trends.

Insert Table 3 about here

\subsection{Demographic Analysis}

Finally, the results of the solar hybrid techno-economic models are combined with demographic data for UP single family homeowners to project the number and proportion of homeowners who will meet grid parity each year 2015-2020 and the number and proportion of these who can afford to invest in a solar hybrid system. The first task is to construct a base population estimate of the total number of seasonal homeowners and the number of full year owner-occupied single family households by household size living in each utility service area. Small-area demographic data from US Census 2010 at the countysubdivision unit of analysis were downloaded via the National Historical Geographic Information System (NHGIS) (Minnesota Population Center 2011) and serve as the building blocks for creating these estimates. Counts of seasonal housing units, year-round owner-occupied housing units, and households by household size are directly available. County subdivisions are an appropriate unit of analysis because, in Michigan, they follow Minor Civil Division boundaries, the smallest functioning unit of government, and reasonably follow utility service areas in the UP. There is little error associated with these counts because they are derived from the fully enumerated population at Census 2010. There has been very little population change in the UP since Census 2010, or for the preceding decade, so the study assumes that the number of households (by type- seasonal vs permanent- and size) for all county subdivisions will remain stable at observed 2010 values through 2020.

Housing units recorded at Census 2010 as "for seasonal, recreational, or occasional use" are used to measure the number of seasonal households. Similarly, the number of owner-occupied housing units of various household sizes are available from Census 2010. This study focuses on single family owneroccupied housing units (which excludes multi-unit condos, etc.). Data from the American Community Survey (ACS 2008-2012) Public Use Microdata Sample (PUMS) 5\% sample for the two Public Use Microdata Areas (PUMAs) in Michigan's UP (available from IPUMS-USA, see Ruggles, et al. 2010) are used to calculate the percent of all owner-occupied housing units that are single family (either attached or detached) by household size. These proportions range from $90 \%$ for 1-person households to $99 \%$ for 6 -ormore person households. The rates are assumed constant across all county subdivisions within the UP. The proportions are then multiplied by the number of owner occupied housing units by household size observed at Census 2010 to estimate single family households.

In order to integrate with the techno-economic results, census data must be aggregated to utility service area units. Maps of utility service areas provided by the Michigan Public Service Commission were used to classify each county subdivision by the most dominant utility serving the unit. It is assumed that all households are served by the same utility, though this is not always true in the cases where utility service areas cross county subdivision lines. To deal with these discrepancies, aggregations are controlled so that the overall number of households assigned to each utility approximates the number of customers reported by each utility in their respective ratebooks. See Figure 1 for documentation of how county subdivisions were assigned.

Whether or not households of various types reach grid parity given the design specifications, energy demand, and rate structures described above can then be determined for households of the various sizes and types within each utility service area. When the predicted LCOE for each household type is 
Preprint: Abhilash Kantamneni, Richelle Winkler, Lucia Gauchia, Joshua M. Pearce, Emerging economic viability of grid defection in a northern climate using solar hybrid systems. Energy Policy 95, 378-389 (2016). doi: 10.1016/j.enpol.2016.05.013

lower than the utility rate, then grid parity has been reached. Still, even when LCOE grid parity is reached, some households cannot afford the initial system investment and financing. For this reason, the number and proportion of homeowners who are within the population meeting LCOE grid parity who can afford the investment are also estimated. The estimates rely on multiple layers of assumptions detailed below and should not be taken as reliable estimates of the number of households who will defect from the grid, but rather as rough approximations of the number and proportion of owner-occupied single family homes across the region for whom it makes economic sense to invest in off-grid solar hybrid systems.

It is assumed that seasonal homeowners will be able to afford the investment, regardless of financing because (1) they have lower and more sporadic electric demand so they can do with a smaller and less expensive solar-hybrid system (\$9,174 with no down-payment required as shown below), and (2) they are more likely to have enough wealth and/or dispensable income to cover the cost. Electric demand from seasonal households is considerably less than full-year residences over the course of the year (Utility Ratebooks, 2013), especially in the winter months when solar activity is lower and these homes are less likely to be occupied. This allows for a smaller sized solar-hybrid system that in 2015 is estimated to cost $\$ 9,174$ installed and require no down payment for a Michigan Saves loan. A wide body of research shows that in rural regions seasonal residents tend to have significantly higher incomes than permanent residents (Schewe et al., 2012; Green and Clendenning, 2003; Green et al., 1996; Brehm et al,. 2006; Jennings and Krannich, 2013). For example, the Natural Resources and Community Survey, which was conducted in 2002 in a northern Wisconsin region that is similar to (environmentally and socially) and proximate to this study area, found the mean income in 2002 dollars of seasonal residents to be approximately $\$ 73,000$, more than twice the mean income of permanent residents (Schewe et al., 2012).

For year-round single family homeowners, the number who can afford to get off the grid is estimated by drawing on household income data from the ACS (2008-2012) for county subdivisions (data downloaded from NHGIS, see Minnesota Population Center 2011). Household income is grouped into ten categories, including: less than $\$ 30,000, \$ 30,000-\$ 40,000, \$ 40,000-\$ 50,000 \ldots \$ 100,000$ or more. Because these data are only available for the total household population, the estimate is adjusted in each category using ACS (2008-2012) PUMS data for the entire UP on household income for single family owner-occupied households in comparison to all households. To generate estimates of household income by household size for single family owner occupied homes the proportion of single family owneroccupied households of each household size within each income category in the PUMS data is multiplied by the estimate of households in each income group for each county subdivision. Finally, the county subdivision data is aggregated to utility service areas.

To be clear, between margins of error associated with the ACS data and the multiple assumptions necessary to ascribe a rough estimate of household income for the various household sizes at the county subdivision level, the income-based estimates and related conclusions are rough. They should not be taken at face value for the exact number (or even proportion) but rather as an approximation of the general pattern. Households with an annual income of $\$ 150,000$ or more are assumed to afford investment in system installation and operation. Households making less than $\$ 30,000$ annually are assumed to not be able to afford investing in a solar hybrid system under any circumstance. It is assumed that households with incomes ranging from $\$ 30,000$ to $\$ 149,000$, could potentially invest in a system with financing, depending on the cost of the initial down payment required. Based on the Michigan Saves (2015) program, financing is available for homeowners with a minimum credit score of 640, regardless of home equity. This program provides loans of up to $\$ 30,000$ with no down payment for applicants meeting a credit score of 640 at an interest rate of 4.99\% (Michigan Saves, 2015). According to Money-zine.com about $73 \%$ of people have a credit score equal to or above 650 in November 2013. Credit scores are presumably higher for homeowners, so this may be an underestimate for this study. Nevertheless, it is assumed that $73 \%$ of Upper Peninsula single family homeowners have a credit score high enough to secure financing. With financing and approved credit score, it is assumed that households making at least 
Preprint: Abhilash Kantamneni, Richelle Winkler, Lucia Gauchia, Joshua M. Pearce, Emerging economic viability of grid defection in a northern climate using solar hybrid systems. Energy Policy 95, 378-389 (2016). doi: 10.1016/j.enpol.2016.05.013

$\$ 60,000$ annually will be able to afford a down payment up to $\$ 5,000$; and that households making $\$ 30,000$ to $\$ 59,999$ will not be able to afford any down payment, but could finance a project if the total cost was less than the $\$ 30,000$ loan limit.

These assumptions are based upon the average 2015 US personal savings rate of 5.08\% (US Bureau of Economic Analysis, 2016), which when applied to a household making $\$ 60,000$ (lower bounds) annually suggests that it would take 2 years (upper bounds) to save for a \$5,000 down payment. They are also supported by studies that show recent solar installations are most common in middle-class neighborhoods (household incomes $\$ 40,000-\$ 90,000$ ) and solar is growing most rapidly among households with incomes ranging from $\$ 30,000$ to $\$ 50,000$ (Hernandez 2013). Ultimately, the assumptions (while not perfect) are reasonable and provide a general approximation of households who would both meet grid parity and reasonably be expected to be able to afford investment in an off-grid solar-hybrid system.

\section{Results and Discussion}

\subsection{Results}

Table 4 shows the system designs by household type and associated cost estimates in 2015 (base year) and projected to 2020. PV system sizes range from $1.67 \mathrm{~kW}$ required for seasonal households to 7.7 $\mathrm{kW}$ for full-year residences with at least six household members. Battery sizes range from $3.2 \mathrm{kWh}$ of storage required to almost $15 \mathrm{kWh}$, and one $\mathrm{kW}$ generator is required for all of the full-year resident households. It is assumed that seasonal households will not require a generator, because their primary electric demand will be in the summer seasons when PV and storage can meet most of their needs. Total installment costs for seasonally occupied homes are approximately \$9,200 currently in 2015 and are projected to gradually drop to about $\$ 4,600$ in 2020 as battery and solar photovoltaic module costs decline. Year-round home system costs range from $\$ 18,200$ (lowest consuming) to $\$ 37,600$ (highest consuming) in 2015 and drop to \$8,300 (lowest consuming) to \$16,300 (highest consuming) in 2020. Down payments are only required for loans greater than $\$ 30,000$. Annual costs include the costs of natural gas and maintenance. The LCOE, then, includes financing costs, annual maintenance costs, and replacement costs for components at the end of their operating lifetime.

\section{Insert Table 4 about here}

Based on these specifications and prospective future electric rates, Figure 2 shows the points at which the off-grid system meets grid parity among UP utilities for seasonal (a) and for year-round (b) homeowners. Figure 2a shows that already in 2015 seasonal homeowners living within the Ontonagon County Rural Electrification Association (REA) service area have reached grid parity. This is because of a combination of high effective rates $(\$ 0.50 / \mathrm{kWh})$ for seasonal homeowners and relatively low energy demand and corresponding solar hybrid system size and upfront costs. The slope of the LCOE line steadily declines over the next five years, at the same time that utility rates are projected to continue to increase. By 2020, several utility service areas are projected to have reached grid parity for seasonal homeowners.

Insert Figure 2 about here

Figure $2 \mathrm{~b}$ demonstrates that currently in 2015 there are no utility service areas in the UP where LCOEs for the specified solar-hybrid system described here reach grid parity for year-round residents. However, as solar and battery components are projected to decline in cost and utility rates to increase, year-round single family homeowners in several of the utility service areas should start to reach grid parity by 2018 and the majority by 2020 .

Table 5 shows projected numbers of grid parity estimates for seasonal and year-round households. More detailed estimates by household size and income (described in methods section above) were aggregated to generate these totals. Results show that a small number of seasonal households can begin profiting from leaving the grid in the UP now. The more substantial investment needed for year- 
Preprint: Abhilash Kantamneni, Richelle Winkler, Lucia Gauchia, Joshua M. Pearce, Emerging economic viability of grid defection in a northern climate using solar hybrid systems. Energy Policy 95, 378-389 (2016). doi: 10.1016/j.enpol.2016.05.013

round households (with higher demand and thus larger and more costly systems) begins to provide a profit for defecting from the grid for a small number of customers with the highest electric rates in 2016 and then in greater and growing numbers by 2017. By 2018, it is projected that over 50,000 single family owner-occupied households in the UP will reach grid parity, qualify for a loan, and be able to afford any required down payment; thus it will make economic sense for these households to defect from the grid with the specified solar-hybrid system. By 2020, this number increases to over 85,000 as costs decrease and utility rates increase. Note that while almost 70,000 year-round households are projected to reach grid parity by 2020 , only about $68 \%$ of them $(47,525)$ will be able to get and afford financing to install a system, following the assumptions described above.

\section{Insert Table 5 about here}

Table 6 shows the estimated percentage of single-family homeowners reaching grid parity. Roughly 5\% of seasonal households would achieve grid parity as of 2015, and by $2020,92 \%$ of seasonal households would have reached grid parity. For year-round households, significant proportions (38\%) reach grid parity by 2017 and about three-quarters by 2020. All of these households, however, may not be able to secure a loan and afford financing the off-grid systems. The total number of households projected to have reached grid parity and be able to afford to defect are shown in the last column of Table 6 . Approximately two-thirds of single-family owner-occupied housing units (seasonal and year round together) would afford to go off grid by 2020 with $4.99 \%$ financing.

\section{Insert Table 6 about here}

\subsection{Discussion}

The percentage of potential grid defectors that would be able to produce their own electricity with a combination of solar photovoltaic cells, batteries and natural gas fired CHP systems at a lower cost than conventional grid-based utilities is substantial, reaching about $82 \%$ of single-family owner-occupied seasonal and year-round residents in the Upper Peninsula of Michigan by 2020. Rough projections indicate that the majority of those surpassing grid parity (about 65\%) will be able to afford the systems with modest loans at reasonable rates. These projections provide a summary of how technological change and economic cost reductions in alternative energy technologies are beginning to shift household economic incentives away from grid-tied electricity.

It is crucial to recognize, however, that the projections shown here focus solely on the economic feasibility of defecting from the electric utility grid. This is an important distinction from projecting the number of households who will defect. There are many reasons why (and why not) households decide to invest in alternative energies and there are many additional factors impacting decisions to connect to the electric grid or not. Beyond high initial costs and perceived lack of financing options, common social barriers include lack of institutional support and inert social norms (Goldthau, 2014), poor consumer knowledge, low customer confidence, inadequate workforce skills, concerns about aesthetics of renewable systems (Margolis \& Zuboy, 2006; Schelly, 2014) and the uncertainty, risk and liability of grid defection (Moody's, 2015; Khalilpour \& Vassallo, 2015). Moreover, substitution effects whereby households choose to purchase other consumer goods or to make alternative investments over investing in a solar hybrid system will also reduce the number of households who ultimately make the choice to defect from the grid. Concern about climate change and/or energy security and independence might increase the likelihood that households would adopt off-grid solar hybrid systems regardless of economic rationality.

The more households who do follow economic feasibility and defect from the grid, the more circumstances for a positive feedback loop would be likely to emerge. As more people in a given community visibly defect from the grid a catalytic effect can be anticipated that could have the effect of accelerating PV system adoption (McKenzie-Mohr, 2013; Schelly, 2014). When households defect from the grid, the majority of utility sunk costs remain constant while customer revenue is decreased (Graffy \& Kihm, 2014), which would presumably lead to higher rates and more households crossing the grid parity line and choosing defection (Agnew and Dargusch 2015). This could result in something like what has 
Preprint: Abhilash Kantamneni, Richelle Winkler, Lucia Gauchia, Joshua M. Pearce, Emerging economic viability of grid defection in a northern climate using solar hybrid systems. Energy Policy 95, 378-389 (2016). doi: 10.1016/j.enpol.2016.05.013

been popularly discussed as the utility "death spiral”, as is becoming a popular depiction among utilities and the media (Edison Electric Institute 2013, Parkinson 2014; Graffy \& Kihm, 2014).

In the UP case, it appears that the economic conditions for such a "death spiral" are imminent, given current and emerging utility rate structures, energy consumption patterns, and system costs. Opportunities for grid-tied net metering or community solar, however, could change the incentive structure. This paper has evaluated economic incentives associated with off-grid solar hybrid systems in comparison only to traditional grid-based utility service. It did not factor in potential for grid-tied solar PV as another option. Net metering may be more economically attractive than off-grid systems for many households if sufficient opportunities to net meter are available and if associated rate structures are favorable. Net-metering offers significantly more savings relative to behind-the-meter, time of use and other PV compensation mechanisms (Darghouth et. al., 2014) while providing added benefits of reliability and security. From the producer/customer ("prosumer") standpoint, grid defection may only be attractive in cases where net-metering is either unavailable or uneconomical. Although it should be pointed out that a third model is of community solar is increasing in popularity where the installation of a single large PV system, usually in coordination with the local municipal utility, with community members either purchasing proportional ownership in the system or subscribing to representational "shares" in it (Coughlin and Cory, 2009 ).

Currently, in Michigan net metering does exist and would present a smaller capital investment for utility customers considering PV systems, however, Michigan Senate Bill 438 currently pending before legislation proposes replacing net-metering with credits at wholesale rates for all electricity generated by a customer owned solar PV system (MISB, 2015). This radically reduces the economic value of owning a grid-tied PV system from a "prosumer" perspective. The proposal itself creates risk for potential PV net metered customers, and so we might expect that it would retard PV penetration and favor grid defection for those considering PV systems. Similarly, if Bill 438 is passed it could radically shift the economic best option for electric customers considering a PV system from a net metered system to grid defection.

Net metering policies have been popular across the U.S. with 44 states plus Washington DC having authorized net metering (National Conference of State Legislatures, 2014). Policies vary from state to state in terms of capacity limits, eligible technologies (CHP for instance does not always count), compensation programs, ownership of renewable energy credits, and whether aggregated or community net metering is allowed (NCSL, 2014). Net metering can benefit utilities by creating a financial incentive for customers to avoid grid defection.

However, many utilities and policy makers see net metering programs as a threat to conventional grid-based energy supply. In response, utilities have been using a number of mechanisms meant to discourage distributed renewable energy generation including: i) trying to rescind net metering legislation (WI, 2013; CO, 2013; KS, 2014; NC, 2014; VA, 2014 ); ii) placing caps on distributed generation (IREC, 2013; HI, 2014); iii) specific solar grid charges (AZ, 2013; GA, 2013; ID, 2013; REW, 2014; UT, 2014); iv) the continued manipulation of customer charges to act as disincentives of both energy efficiency and distributed renewable energy (Sterzinger, 1981; Pearce and Harris, 2007; CA 2014; IL 2014); and v) placing moratoriums and temporary freezes on state Renewable Portfolio Standards (IBT, 2014). These tactics raise the cost of grid-tied PV systems and frustrate many customers (McLaren. et al, 2015; MEnN, 2015; Fortune, 2016). In addition, all of these efforts provide PV prosumers an economic incentive for grid defection.

\subsection{Generalizing from the UP Case}

The UP case is unique in that population densities are very low, winter weather is extreme, incomes are relatively low, and electrical rates among several of the utilities are quite high. Still, this case provides an important detailed example of economic incentives for grid defection and lessons can be extrapolated to other areas if the specifics of utility rates, solar energy potential, energy demand, and socioeconomic structures are considered. In fact, because of its low solar potential and low income 
Preprint: Abhilash Kantamneni, Richelle Winkler, Lucia Gauchia, Joshua M. Pearce, Emerging economic viability of grid defection in a northern climate using solar hybrid systems. Energy Policy 95, 378-389 (2016). doi: 10.1016/j.enpol.2016.05.013

population, the UP case represents a relatively difficult market for off-grid solar-hybrid systems. If it is economically feasible to defect from the grid here, then it might be even more likely elsewhere.

Utility rates in the UP range (on the low-end) from around the US average to more than twice the US average, so the impact of utility rate structures is relatively representative of the typical US homeowner to those living in other high cost areas. The results show that for households living in service areas with the lowest electric rates in the UP (those serviced by municipally-owned utilities and by the Wisconsin Public Service Commission), LCOEs for the specified solar-hybrid system do not drop below utility rates by 2020. On the other hand, for those utilities with rates around twice the national average, LCOEs reach grid parity by 2018. Solar energy potential also varies considerably across the United States and around the world. Solar potential is relatively low in the UP, in comparison to much of the United States and certainly much lower than that seen in the Southwestern US. Solar potential is greater than what would be found in Alaska and similar to that seen across the Upper Midwest and Northeastern US (National Renewable Energy Laboratory, 2015). Grid parity may be reached sooner in areas with higher solar productivity.

Energy demand (household consumption) in the UP is relatively low (about 8,335 kWh annually) compared to the US average $(10,908 \mathrm{kWh})$. This means that the system design specified in this paper may be undersized for regions with higher consuming households. LCOEs for larger systems would be correspondingly higher. The analysis shown here did consider higher energy demand among larger households with 6-person households showing consumption similar to the national average (see Table 2). Results show that these higher demand households were among the first to reach grid parity.

As discussed previously incomes are relatively low in the UP, with median household income about $77 \%$ of the U.S. median household income. This means that fewer households in the UP would be able to finance an off-grid solar hybrid system than what might be seen in other regions. Altogether, the analysis indicates that regions with average to high electrical rates, with average-high solar potential, with average-high energy demand, and with average-high incomes could see similar or even greater economic incentive for grid defection than the UP. Regions with lower than average utility rates, on the other hand, would see little economic incentive for defection in the short term.

\subsection{Limitations}

It must be clear that this analysis is based upon projections of future conditions based on a set of assumptions about future household and income structures, utility rates, and solar photovoltaic, battery, CHP, and natural gas costs. The assumptions are generally based upon current conditions, recent past trends (in utility rate changes and population structures), and industry-based predictions of technology cost reductions. Any number of social, economic, policy, or technological changes could alter the conditions upon which the projections shown here were developed. Transaction costs were not figured into the economic viability analysis. These could be considerable as households must invest time and energy to researching solar hybrid systems, finding trusted installers, overseeing installation work, and learning to understand and manage the solar hybrid system for their home. On the other hand, one benefit of installing off-grid systems is the ability to generate power during grid power outages. This study did not consider this added benefit that might increase the economic rationality to defect, particularly in regions prone to outages.

The projections shown here do not attempt to forecast the number of households who will defect from the grid or defection rates. It should not be expected that all households for whom it makes economic sense to install a solar hybrid system as discussed here will actually do so. As mentioned before, there are multiple social, economic, cultural, and technical factors that shape technological adoption (Margolis \& Zuboy, 2006; Schelly, 2014).

Throughout the projection process, the assumptions have aimed to be conservative, such that the models would be more likely to underestimate the likelihood of reaching grid parity, with perhaps the most conservative assumption being intrinsic to the system design itself. None of the systems were 
Preprint: Abhilash Kantamneni, Richelle Winkler, Lucia Gauchia, Joshua M. Pearce, Emerging economic viability of grid defection in a northern climate using solar hybrid systems. Energy Policy 95, 378-389 (2016). doi: 10.1016/j.enpol.2016.05.013

optimized for economic output. In the real economy customers and system suppliers will attempt to find the closest to ideal system for a given household. To run this optimization routine the exact cost of all the components, any losses (e.g. shading) and the borrowing costs are needed. It should be pointed out here that this analysis was performed with no shading losses and that not all houses are technically well-suited for solar PV. However, in general, in the UP households are on substantial plots that allow for the space necessary for a reasonably un-obstructed PV array (e.g. on ground mounts in the yard if not on the roof). Thus, in general, the systems designed using a proper life cycle methodology will have a lower LCOE than what was calculated here, and thus a faster potential to reach grid parity from what is shown in the results.

In addition, as the markets for solar and natural gas generators continue to expand, there is an opportunity to significantly improve the performance of hybrid systems by taking advantage of the waste heat for cogeneration (Pearce, 2009). In these systems waste heat from the generators is used for home heating. This would reduce the heating costs for homeowners and speed the simple payback time for the systems. Photovoltaic arrays coupled to trigeneration could improve the overall energy use even further in some areas (Nosrat et al., 2013). Dispatch strategies used to minimize the overall costs and the emissions of such hybrid systems are well developed (Derewonko \& Pearce, 2009; Nosrat \& Pearce, 2011) and future work can couple these into the economic model to devise optimum systems for a specific region.

\subsection{Broader Impact}

This study modeled the point at which the financial costs of PV+battery+CHP systems reach grid parity for single-family homeowners, using the Upper Peninsula of Michigan as a case study. In addition to isolated states like Hawaii, which has the highest electrical rates in the nation, several utilities in Michigan's UP have relatively high electrical rates. High rates are relatively common across rural areas of the United States because of low-population density (Cooper, 2008; BLS, 2011) and large surface areas to energy use ratios (Nguyen \& Pearce, 2010). The analysis presented here indicates that grid defection may be more likely in rural areas, but further work is necessary to determine if the the results presented here can be generalized across the U.S. In addition, many rural areas, especially those rich in natural amenities and outdoor recreation opportunities, also have a large proportion of housing units that are for seasonal or recreational use by second homeowners (Winkler, Deller, and Marcouiller, 2015). Seasonal residents tend to have higher incomes, more interest in environmental preservation, higher education, and lower and sporadic energy demand than typical rural residents (Schewe et al., 2012; Matarrita-Cascante et al., 2010; Brehm et al., 2006; Jennings and Krannich, 2013). For these reasons, seasonal residents may be particularly interested in alternative energy options and deserve specific consideration as those most likely to consider grid defection. Ultimately the analysis demonstrates the risk that utilities with relatively high effective rates face as the techno-economic environment increasingly shifts economic incentives toward defecting from the grid in favor of self-generating power

\section{Conclusions and Policy Implications}

Utilizing the Upper Peninsula of Michigan as a case study of the economic feasibility of grid defection using a hybrid off-grid system coupling solar photovoltaics, batteries and CHP, this study projects that in the near future a significant fraction of the households in the region will have an economic incentive and the financial means to defect from the grid. The results show that in regions with high gridbased utility costs, it will soon make economic sense for households with both small and large energy demand to self-generate power. Ultimately, this implies that utility companies and policy makers must take the potential for grid defection seriously when evaluating energy supply strategies.

Many utilities are currently approaching distributed generation from solar and other technologies as a threat and are responding by trying to limit grid penetration (e.g. shifting consumer costs from electric rates to unavoidable customer charges or eliminating net metering policies). The results of this paper suggest that, given emerging techno-economic conditions, the near-term impact of policies and 
Preprint: Abhilash Kantamneni, Richelle Winkler, Lucia Gauchia, Joshua M. Pearce, Emerging economic viability of grid defection in a northern climate using solar hybrid systems. Energy Policy 95, 378-389 (2016). doi: 10.1016/j.enpol.2016.05.013

practices that increase the costs of grid-tied electricity (including those that discourage grid-tied distributed generation) could risk accelerating the rate that utility customers simply leave the grid in favor of less expensive self-generated power. Implications are that the future of grid-tied electricity relies on maintaining relatively low electric rates as the costs of solar and hybrid systems decline. It may also be critical to offer opportunities to integrate distributed generation (from solar, wind, and other sources) to the grid system as concerns about climate change and consumer demand for renewables and local or household control of energy production rise. Each household that installs a grid-tied renewable energy system remains a paying customer that continues to support the centralized system. Given the public interest in maintaining a reliable, affordable, and widely accessible electric system, policy debates around net metering must consider the increasingly economically feasible alternative that households would choose to leave the centralized grid entirely should utility rates get too high or should interest in renewable and locally-controlled generation be left unsupported.

\section{Acknowledgements}

The authors would like to thank L. E. Brown and A. Wellstead for helpful discussions, suggestions, and support. 
Preprint: Abhilash Kantamneni, Richelle Winkler, Lucia Gauchia, Joshua M. Pearce, Emerging economic viability of grid defection in a northern climate using solar hybrid systems. Energy Policy 95, 378-389 (2016). doi: 10.1016/j.enpol.2016.05.013

\section{References}

Agnew, S. and Dargusch, P. (2015). Effect of residential solar and storage on centralized electricity supply systems, Nature Climate Change, vol. 5, pp. 315-318.

Amine, K., Kanno, R., and Tzeng, Y., Rechargeable lithium batteries and beyond: Progress, challenges, and future directions, Materials Research Society Bulletin, vol. 39, pp. 395-401, May 2014.

ARPA-E 2014, APRA-E Workshop on Small Engines, Chicago IL, Available at http://arpae.energy.gov/sites/default/files/Mike\%20Cocking Marathon.pdf

Ashari, M., \& Nayar, C. V. (1999). An optimum dispatch strategy using set points for a photovoltaic (PV)-diesel-battery hybrid power system. Solar Energy, 66(1), 1-9.

AZ, 2013. Arizona Approves Grid-Connection Fees for Solar Rooftops, Available at http://www.bloomberg.com/news/2013-11-15/arizona-regulators-impose-power-grid-fees-forsolar-roofs.html

Barbose, Galen, Naïm Richard Darghouth, Samantha Weaver, David Feldman, Robert Margolis, and Ryan Wiser. "Tracking US photovoltaic system prices 1998-2012: a rapidly changing market." Progress in Photovoltaics: Research and Applications (2014).

Bazilian, Morgan, Ijeoma Onyeji, Michael Liebreich, Ian MacGill, Jennifer Chase, Jigar Shah, Dolf Gielen, Doug Arent, Doug Landfear, and Shi Zhengrong. "Re-considering the economics of photovoltaic power." Renewable Energy 53 (2013): 329-338.

Bernal-Agustín, J. L., \& Dufo-López, R. (2009). Simulation and optimization of stand-alone hybrid renewable energy systems. Renewable and Sustainable Energy Reviews, 13(8), 2111-2118.

BNEF, 2012. Re-imagining US Solar Financing. US Solar - White Paper, Bloomberg New Energy Finance. Available at: <http://www.scsrenewables.com/scsimages/BNEF\%20Re-imagining \%20US\%20Solar\%20Financing.pdf $>$.

BLS, 2011. Expenditures of urban and rural households in 2011, Bureau of Labor Statistics, Prices and Spending. Available at http://www.bls.gov/opub/btn/volume-2/expenditures-of-urban-and-ruralhouseholds-in-2011.htm

Branker, K., Pearce, J.M., 2010. Financial Return for Government Support of Large-Scale Thin-Film Solar Photovoltaic Manufacturing in Canada. Energy Policy, 38, pp. 4291-4303.

Branker, K., M.J.M. Pathak, J.M. Pearce, 2011. A Review of Solar Photovoltaic Levelized Cost of Electricity. Renewable and Sustainable Energy Reviews, 15, 4470-4482.

Breyer, Christian, and Alexander Gerlach. "Global overview on grid-parity." Progress in photovoltaics: Research and Applications 21, no. 1 (2013): 121-136.

Burtraw, Dallas, Karen Palmer, Anthony Paul, Blair Beasley, and Matt Woerman. "Reliability in the US electricity industry under new environmental regulations." Energy Policy 62 (2013): 1078-1091.

Burtraw, Dallas, Joshua Linn, Karen L. Palmer, and Anthony C. Paul. "The Costs and Consequences of Clean Air Act Regulation of CO2 from Power Plants." Resources for the Future Discussion Paper (2014): 14-01

Brown, R. E., \& Willis, H. L. (2006). The economics of aging infrastructure. Power and Energy Magazine, IEEE, 4(3), 36-43.

CA, 2014 Utilities seek electric rate increases. The Desert Sun. Available at http://www.desertsun.com/story/money/business/2014/04/22/rooftop-solar-southern-californiaedison-utilities-seek-electric-rate-increases/7995093/

Candelise, Chiara, Mark Winskel, and Robert JK Gross. "The dynamics of solar PV costs and prices as a challenge for technology forecasting." Renewable and Sustainable Energy Reviews 26 (2013): 96-107.

Celebi, M., Graves, F., \& Russell, C. (2012). Potential coal plant retirements: 2012 update. Washington DC: Brattle Group. Accessed September, 12, 2013. 
Preprint: Abhilash Kantamneni, Richelle Winkler, Lucia Gauchia, Joshua M. Pearce, Emerging economic viability of grid defection in a northern climate using solar hybrid systems. Energy Policy 95, 378-389 (2016). doi: 10.1016/j.enpol.2016.05.013

Chalmers, S.M. , M.M. Hitt, J.T. Underhill, P.M. Anderson, P.L. Vogt, and R. Ingersoll, 1985. The Effect of Photovoltaic Power Generation on Utility Operation”. IEEE Transactions on Power Apparatus and Systems 104(3), 1985, pp. 524530.

CO, 2013. Colorado PUC keeps net metering in place for now. IREC February 12 2014. Available at http://www.irecusa.org/2014/02/colorado-puc-keeps-net-metering-in-place-for-now/

Cooper, J.. "Electric Co-Operatives: From New Deal to Bad Deal." Harv. J. on Legis. 45 (2008): 335.

Coughlin, J. and Cory, K.S., Solar photovoltaic financing: residential sector deployment. National Renewable Energy Laboratory (2009).

Dalecki, M.G. and C.M. Coughenour. 1992. Agrarianism in American Society. Rural Sociology 57(1): 48-64.

Darghouth, N. R., Barbose, G., \& Wiser, R. H. (2014). Customer-economics of residential photovoltaic systems (Part 1): The impact of high renewable energy penetrations on electricity bill savings with net metering. Energy Policy, 67, 290-300.

De Cian, E., Sferra, F., \& Tavoni, M. (2013). The influence of economic growth, population, and fossil fuel scarcity on energy investments. Climatic Change, 1-17.

Derewonko, P., \& Pearce, J. M. (2009, June). Optimizing design of household scale hybrid solar photovoltaic + combined heat and power systems for Ontario. In Photovoltaic Specialists Conference (PVSC), 2009 34th IEEE (pp. 001274-001279). IEEE.

DOE, 2013. U.S. Department of Energy, Grid Energy Storage, September 2013.

Edison Electric Institute. 2013. "Disruptive Challenges: Financial implications and strategic responses to changing retail electric business.” Edison Electric Institute Report. Prepared by Peter Kind of Energy Infrastructure Advocates. Accessed online on August 18, 2014 at http://www.eei.org/ourissues/finance/documents/disruptivechallenges.pdf

EIA. 2009. Residential Energy Consumption Survey (RECS) http://www.eia.gov/consumption/residential/data/2009/

EIA. 2015. “How much electricity does an American home use?” Frequently Asked Questions. Accessed online on August 21, 2015 at http://www.eia.gov/tools/faqs/faq.cfm?id=97\&t=3.

EIA-AEO, 2015. US Energy Information Administration Annual Energy Outlook 2015. http://www.eia.gov/forecasts/aeo/pdf/0383(2015).pdf

Feldman, David. (2014). Photovoltaic (PV) Pricing Trends: Historical, Recent, and Near-Term Projections . Lawrence Berkeley National Laboratory: Lawrence Berkeley National Laboratory. LBNL Paper LBNL-6019E. Retrieved from: http://escholarship.org/uc/item/06b4h95q

Fortune, 2016. Fortune Magazine "Nevada’s New Solar Fees Have People Furious". Available at http://fortune.com/2016/01/14/nevada-solar-battleground/

GA, 2013. PSC Staff recommends against Georgia Power solar fee, OnlineAthens. Available at http://onlineathens.com/local-news/2013-10-18/psc-staff-recommends-against-georgia-powersolar-fee

Gerrard, Michael B., and Shelley Welton. "US Federal Climate Change Law in Obama’s Second Term†." Transnational Environmental Law 3, no. 01 (2014): 111-125.

Goldthau, A. (2014). Rethinking the governance of energy infrastructure: Scale, decentralization and polycentrism. Energy Research \& Social Science 1: 134-140.

Graffy, E., \& Kihm, S. (2014). Does Disruptive Competition Mean a Death Spiral for Electric Utilities?. Energy LJ, 35, 1-219.

Green, G.P. and G. Clendenning. (2003). Seasonal homes. Pp. 1210-1213 in Encyclopedia of Community, K. Christensen and D. Levinson (eds.). Thousand Oaks, CA: Sage Publications.

Green, G.P., D. Marcouiller, S. Deller, D. Erkkila, and N.R. Sumathi. (1996). Local dependency, land use attitudes, and economic development: comparisons between seasonal and permanent residents. Rural Sociology 61: 427-445. 
Preprint: Abhilash Kantamneni, Richelle Winkler, Lucia Gauchia, Joshua M. Pearce, Emerging economic viability of grid defection in a northern climate using solar hybrid systems. Energy Policy 95, 378-389 (2016). doi: 10.1016/j.enpol.2016.05.013

GTM. 2015. U.S. Solar Market Insight Report. http://www.greentechmedia.com/research/ussmi

Gupta, A., Saini, R. P., \& Sharma, M. P. (2010). Steady-state modelling of hybrid energy system for off grid electrification of cluster of villages. Renewable Energy, 35(2), 520-535.

Hernandez, M. (2013). Solar power to the people: The rise of rooftop solar among the middle class. Center for American Progress. Report available at https://cdn.americanprogress.org/wpcontent/uploads/2013/10/RooftopSolarv2.pdf. Accessed 2/29/2016.

HI, 2014. HECO: 80 percent of circuits on Oahu have room for solar. CivilBeat. Available at http://www.civilbeat.com/2013/10/20211-fact-check-heco-80-percent-of-circuits-on-oahu-haveroom-for-solar/

Hrayshat, E. S. (2009). Techno-economic analysis of autonomous hybrid photovoltaic-diesel-battery system. Energy for Sustainable Development, 13(3), 143-150.

IBT, 2014. Ohio Gov. Kasich to Sign "Freeze" On State Clean Energy Mandate By Saturday, Available at www.ibtimes.com/ohio-gov-kasich-sign-freeze-state-clean-energy-mandate-saturday-1598602

ID, 2013. Idaho PSC improves net metering rules for Idaho Power, IREC 2013. Available at http://www.irecusa.org/2013/07/idaho-psc-improves-net-metering-rules-for-idaho-power/

IEA, 2014. Technology Roadmap. Solar Photovoltaic Energy. Available at: https://www.iea.org/media/freepublications/technologyroadmaps/solar/TechnologyRoadmapSolar PhotovoltaicEnergy 2014edition.pdf

IL, 2014 Chicago electric bills to rise up to 18\% in June under new Integrys deal. ChicagoBusiness. Available at http://www.chicagobusiness.com/article/20140309/NEWS11/140309785/chicagoelectric-bills-to-rise-up-to-18-in-june-under-new-integrys-deal

IREC, 2012. U.S. Solar Market Trends 2011. Interstate Renewable Energy Council, Available at: <http://www.irecusa.org/wp-content/uploads/IRECSolarMarketTrends-2012-Web-8-28-12.pdf > .

IREC, 2013 Best Practices in State Net Metering and Interconnection Procedures, Freeing The Grid, Available at http://freeingthegrid.org/wp-content/uploads/2013/11/FTG 2013.pdf

Jewell,W.T. and T.D. Unruh, 1990. Limits on Cloud induced Fluctuation in Photovoltaic Generation. IEEE Transactions on Energy Conversion 5(1), 1990, pp. 814.

KS, 2014. Kansas House Bill 2458. Available at http://www.kslegislature.org/li/b2013 14/measures/documents/hb2458 00 0000.pdf

Khalilpour, R., \& Vassallo, A. (2015). Leaving the grid: An ambition or a real choice?. Energy Policy, 82, 207-221.

Kriegler, Elmar, Ioanna Mouratiadou, Gunnar Luderer, Nico Bauer, Katherine Calvin, Enrica DeCian, Robert Brecha et al. "Roadmaps towards Sustainable Energy futures and climate protection: A synthesis of results from the RoSE project." Potsdam Institute for Climate Impact Research, Potsdam (2013).

Li, Z., \& Guo, J. (2006). Wisdom about age [aging electricity infrastructure]. Power and Energy Magazine, IEEE, 4(3), 44-51.

Linn, Joshua, Erin Mastrangelo, and Dallas Burtraw. "Regulating Greenhouse Gases from Coal Power Plants under the Clean Air Act." Journal of the Association of Environmental and Resource Economists 1, no. 1 (2014): 97-134.

McDonald, A., \& Schrattenholzer, L. (2001). Learning rates for energy technologies. Energy policy, 29(4), 255-261.

Margolis, R., \& Zuboy, J. (2006). Nontechnical barriers to solar energy use: review of recent literature. NREL. Technical Report NREL/TP-520-40116.

Matarrita-Cascante, D., R. Stedman, and A. E. Luloff. (2010). “Permanent and Seasonal Residents' Community Attachment in Natural Amenity-Rich Areas: Exploring the Contribution of Landscape-Related Factors.” Environment and Behavior 42:197-220. 
Preprint: Abhilash Kantamneni, Richelle Winkler, Lucia Gauchia, Joshua M. Pearce, Emerging economic viability of grid defection in a northern climate using solar hybrid systems. Energy Policy 95, 378-389 (2016). doi: 10.1016/j.enpol.2016.05.013

McKenzie-Mohr, D. (2013). Fostering sustainable behavior: An introduction to community-based social marketing. New society publishers.

MEnN, 2015. Midwest Energy News “Solar Customers in Michigan's U.P. feel 'Carpet Ripped Out' from under them. Available at - http://midwestenergynews.com/2015/09/18/solar-customers-inmichigans-u-p-feel-carpet-ripped-out-from-under-them/

Michigan Saves. 2015. Available: http://michigansaves.org/

Minnesota Population Center. 2011. National Historical Geographic Information System: Version 2.0. Minneapolis, MN: University of Minnesota.

MISB, 2015. Michigan Senate Bill 438. Available at:- http://legislature.mi.gov/documents/20152016/billintroduced/Senate/htm/2015-SIB-0438.htm

Moneyzine.com. (2015). “About Credit Scores.” Website accessed August 21, 2015. http://www.moneyzine.com/financial-planning/debt-consolidation/about-credit-scores/

Moody's Investor Service, 2015. "Batteries are coming but utilities are not going away", Available at: http://www.moodys.com/viewresearchdoc.aspx?docid=PBC 1001444

MPSC, 2013. Michigan Electric Utility Company Annual Reports 2013, Michigan Public Services Commission. Available at: http://www.michigan.gov/mpsc/0,1607,7-159-16377 41871214349--,00.html

MPSC, 2015. Comparison of Michigan Electric Utility average electric rates, Michigan Public Service Commission. Available At: http://www.dleg.state.mi.us/mpsc/electric/download/rates1.pdf

MPSC-Gas, 2015. Michigan Natural Gas Utility Rate Books, Michigan Public Services Commission. Available at: http://www.michigan.gov/mpsc/0,1607,7-159-16385-110722--,00.html

Mundada, A. S., Shah, K. K., \& Pearce, J. M. (2016). Levelized cost of electricity for solar photovoltaic, battery and cogen hybrid systems. Renewable and Sustainable Energy Reviews, 57, 692-703.

Murphy, D. J. "The implications of the declining energy return on investment of oil production." Philosophical Transactions of the Royal Society A: Mathematical, Physical and Engineering Sciences 372, no. 2006 (2014): 20130126.

National Climatic Data Center, 2001. Comparative Climatic Data. National Oceanic and Atmospheric Administration (NOAA).

National Conference of State Legislatures. (2014). Net metering: Policy overview and state legislative updates. Report published online 9/26/2014 available at http://www.ncsl.org/research/energy/netmetering-policy-overview-and-state-legislative-updates.aspx. Accessed 2/29/2016.

Nemet, G. F. (2006). Beyond the learning curve: factors influencing cost reductions in photovoltaics. Energy policy, 34(17), 3218-3232.

NERA, 2014: Potential Energy Impacts of the EPA Proposed Clean Power Plan, NERA Economic Consulting. Available at: http://americaspower.org/sites/default/files/NERA CPP \%20Report Final Oct\%202014.pdf

Nguyen, H. T., \& Pearce, J. M. (2010). Estimating potential photovoltaic yield with $<\mathrm{i}>\mathrm{r}$. $\operatorname{sun}</ \mathrm{i}>$ and the open source Geographical Resources Analysis Support System. Solar energy, 84(5), 831-843.

NC, 2014 Net-Metering in 2014: Where the first battles will be fought. Renewable Energy World. Available at: http://www.renewableenergyworld.com/rea/news/print/article/2014/01/netmetering-in-2014-where-the-first-battles-will-be-fought

Nosrat, A., \& Pearce, J. M. (2011). Dispatch strategy and model for hybrid photovoltaic and trigeneration power systems. Applied Energy, 88(9), 3270-3276.

Nosrat, A. H., Swan, L. G., \& Pearce, J. M. (2013). Improved performance of hybrid photovoltaictrigeneration systems over photovoltaic-cogen systems including effects of battery storage. Energy, 49, 366-374.

Nosrat, A. H., Swan, L. G., \& Pearce, J. M. (2014). Simulations of greenhouse gas emission reductions from low-cost hybrid solar photovoltaic and cogeneration systems for new communities. 
Preprint: Abhilash Kantamneni, Richelle Winkler, Lucia Gauchia, Joshua M. Pearce, Emerging economic viability of grid defection in a northern climate using solar hybrid systems. Energy Policy 95, 378-389 (2016). doi: 10.1016/j.enpol.2016.05.013

Sustainable Energy Technologies and Assessments, 8, 34-41.

NREL, 2014. National Solar Radiation Data Base 1991- 2005 Update: Typical Meteorological Year 3. Available: http://rredc.nrel.gov/solar/old data/nsrdb/1991-2005/tmy3/by state and city.html\#M

Parkinson, G. 2014. "Tipping point nears for abandoning the utility and going off-grid. Renew Economy. March 27, 2014. Accessed online Aug 18, 2014 at

http://www.greentechmedia.com/articles/read/Tipping-Point-Nears-for-Abandoning-the-Utilityand-Going-Off-Grid

Pathak, M. J. M., Sanders, P. G., \& Pearce, J. M. (2014). Optimizing limited solar roof access by exergy analysis of solar thermal, photovoltaic, and hybrid photovoltaic thermal systems. Applied Energy, $120,115-124$.

Pearce J.M., 2002. Photovoltaics - a path to sustainable futures. Futures, 34(7), pp. 663-674(12).

Pearce, J. M. (2009). Expanding photovoltaic penetration with residential distributed generation from hybrid solar photovoltaic and combined heat and power systems. Energy, 34(11), 1947-1954.

PSC, 2014. Electric Reliability in Michigan: The Challenge Ahead, Public Sector Consultants http://www.pscinc.com/LinkClick.aspx?fileticket $=$ CuGsO5sdBOs\%3D\&tabid=75

Pratson, Lincoln F., Drew Haerer, and Dalia Patiño-Echeverri. "Fuel Prices, Emission Standards, and Generation Costs for Coal vs Natural Gas Power Plants." Environmental Science \& Technology 47, no. 9 (2013): 4926-4933.

Prindle, B., Eldridge, M., Eckhardt, M., Frederick, A., 2007. The Twin Pillars of Sustainable Energy: Synergies between Energy Efficiency and Renewable Energy Technology and Policy. American Council for an Energy-Efficient Economy. Report number : E074.

Pudasainee, D., Kim, J. H., \& Seo, Y. C. (2009). Mercury emission trend influenced by stringent air pollutants regulation for coal-fired power plants in Korea. Atmospheric Environment, 43(39), 6254-6259.

Reichelstein, Stefan, and Michael Yorston. "The prospects for cost competitive solar PV power." Energy Policy 55 (2013): 117-127.

Rallo, Manuela, M. Antonia Lopez-Anton, M. Luisa Contreras, and M. Mercedes Maroto-Valer. "Mercury policy and regulations for coal-fired power plants." Environmental Science and Pollution Research 19, no. 4 (2012): 1084-1096.

REW, 2014. NRDC and U.S. Utilities Urge Grid Payments for Rooftop Solar, Available at http://www.renewableenergyworld.com/rea/news/article/2014/02/nrdc-and-u-s-utilities-urge-gridpayments-for-rooftop-solar

RMI. 2014. Economics of Grid Defection: When and Where Distributed Solar Generation Plus Storage Competes with Traditional Utility Service. Rocky Mountain Institute, Colorado.

Ruggles, S., Alexander, J.T., Genadek, K., Goeken, R., Schroeder, M.B.,and M. Sobek. Integrated Public Use Microdata Series: Version 5.0 [Machine-readable database]. Minneapolis: University of Minnesota, 2010.

Sadeghi, S., \& Ameri, M. (2012). Comparison the Combination of Different Power Generators with Photovoltaic Panels and Batteries. In Computer Applications for Security, Control and System Engineering (pp. 376-387). Springer Berlin Heidelberg.

Sadeghi, S., \& Ameri, M. (2014). Comparison of different power generators in PV-battery-power generator hybrid system. Journal of Mechanical Science and Technology, 28(1), 387-398.

Schelly, C. (2014). Residential Solar Electricity Adoption: What Motivates, and What Matters? A Case Study of Early Adopters. Energy Research and Social Science. 2, pp. 183-191.

Schewe, R. and D.R. Field. (2012). Condos in the Woods: The Growth of Seasonal and Retirement Homes in Northern Wisconsin. University of Wisconsin Press.

SEIA. 2011. U.S. Solar Market Insight: Year-in-Review-2010. Solar Energy Industries Association, Washington, D.C. 
Preprint: Abhilash Kantamneni, Richelle Winkler, Lucia Gauchia, Joshua M. Pearce, Emerging economic viability of grid defection in a northern climate using solar hybrid systems. Energy Policy 95, 378-389 (2016). doi: 10.1016/j.enpol.2016.05.013

SEIA, 2013. Solar Energy Facts: Q2 2013. Solar Energy Industries Association, Washington, D.C. Available at: http://www.seia.org/sites/default/files/Q2\%202013\%20SMI\%20Fact \%20Sheetv2.pdf.

SEIA. 2014. U.S. Solar Market Insight: Year-in-Review-2014 Q1. Solar Energy Industries Association, Washington, D.C.

Shah, K.K.,Mundada, A.S. Pearce. J.M. 2015. Performance of U.S. hybrid distributed energy systems: Solar photovoltaic, battery and combined heat and power. Energy Conversion and Management 105, 71-80.

Shahan, Z. 2015. Tesla Powerwall \& Powerpacks Per-kWh Lifetime Prices vs Aquion Energy, Eos Energy, \& Imergy http://cleantechnica.com/2015/05/09/tesla-powerwall-powerblocks-per-kwhlifetime-prices-vs-aquion-energy-eos-energy-imergy/

Sterzinger, G.J. 1981. The Customer Charge and Problems of Double Allocation of Costs, Public. Utilities Fortnightly, July 2, 1981, pp. 30-32.

Sweet, C. NRG Energy CEO: Home-Generated Power 'Mortal Threat' to Utilities, WALL ST. J. (Mar. 21, 2013), http://online.wsj.com/article/BT-CO-20130321-710418.html .

Tesla. 2014. Planned 2020 Gigafactory Production Exceeds 2013 Global Production. Tesla. http://www.teslamotors.com/sites/default/files/blog attachments/gigafactory.pdf

Tesla. 2015. PowerWall. Available at: http://www.teslamotors.com/powerwall

Timilsina, G.R., Kurdgelashvili, L., Narbel, P.A., 2012. Solar energy: Markets, economics and policies. Renewable and Sustainable Energy Reviews 16, 449-465.

U.S. Bureau of Economic Analysis. Table 2.3 Personal Income and its Disposition. Available at http://www.bea.gov/iTable/iTable.cfm?ReqID=9\&step=1\#reqid=9\&step=3\&isuri=1\&903=76. Last updated February 26, 2016. Accessed 2/29/2016.U.S. Census Bureau. https://ask.census.gov/faq.php?id=5000\&faqId=5971

UT, 2014. Utah Utility proposes additional net metering fee. IREC 2014. Available at http://www.irecusa.org/2014/01/utah-utility-proposes-additional-net-metering-fee/

van der Zwaan, B., \& Rabl, A. (2003). Prospects for PV: a learning curve analysis. Solar Energy, 74(1), 19-31.

VA, 2014. Dominion Virginia block net metering bill, CleanTechnia 2014. Available at http://cleantechnica.com/2014/02/10/dominion-virginia-power-blocks-net-metering-bill/

Wan, Y. and B.K. Parsons, (1993). Factors Relevant to Utility Integration of Intermittent Renewable Technologies”. National Renewable Energy Laboratory, 1993, NREL/TP4634953.

Watanabe, C., Nagamatsu, A., \& Griffy-Brown, C. (2003). Behavior of technology in reducing prices of innovative goods - an analysis of the governing factors of variance of PV module prices. Technovation, 23(5), 423-436.

Willis, H. L., \& Schrieber, R. R. (2013). Aging power delivery infrastructures (Vol. 35). CRC Press.

Wilson, Elizabeth J., S. Julio Friedmann, and Melisa F. Pollak. "Research for deployment: incorporating risk, regulation, and liability for carbon capture and sequestration." Environmental science \& technology 41, no. 17 (2007): 5945-5952.

Winkler, R., S. Deller, and D. Marcouiller. 2015. Recreational housing and community development: A triple bottom line approach. Growth and Change.

WI 2013, Wisconsin Utility seeks stricter net metering policy, IREC 2013. Available at http://www.irecusa.org/2013/08/wisconsin-utility-seeks-stricter-net-metering-policy/ 
Preprint: Abhilash Kantamneni, Richelle Winkler, Lucia Gauchia, Joshua M. Pearce, Emerging economic viability of grid defection in a northern climate using solar hybrid systems. Energy Policy 95, 378-389 (2016). doi: 10.1016/j.enpol.2016.05.013

\section{Figures}

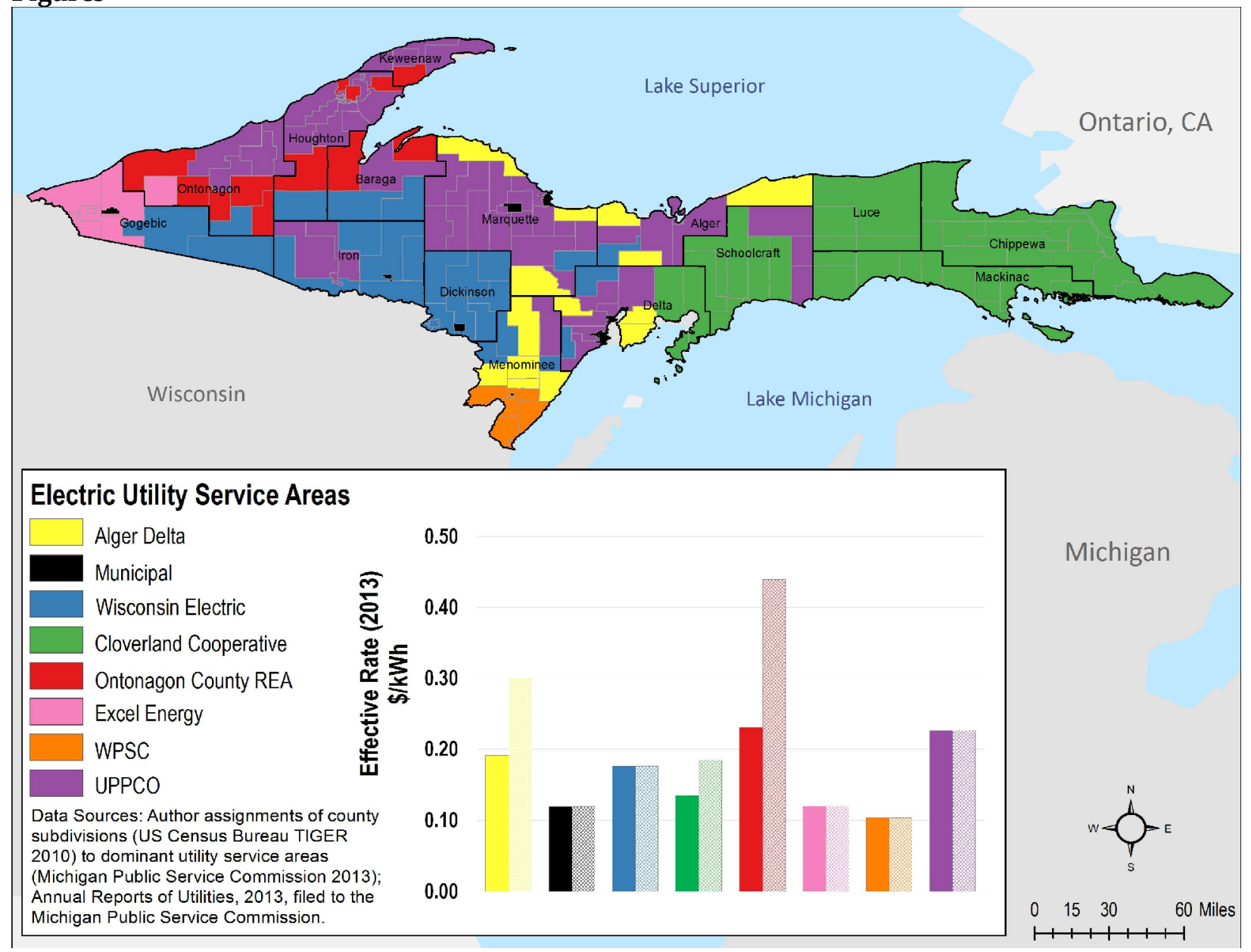

Figure 1: Upper Peninsula of Michigan Electric Utility Service Areas and Rates. Map shows how the authors assigned county subdivisions to specific utility service areas. Color-coding for the map and chart coincide. The chart shows effective electric rates in 2014 (including service fees) for each of the utilities servicing the region. The solid color bars refer to rates charged to year-round customers. The corresponding striped bars refer to rates charged to seasonal customers. 
Preprint: Abhilash Kantamneni, Richelle Winkler, Lucia Gauchia, Joshua M. Pearce, Emerging economic viability of grid defection in a northern climate using solar hybrid systems. Energy Policy 95, 378-389 (2016). doi: 10.1016/j.enpol.2016.05.013

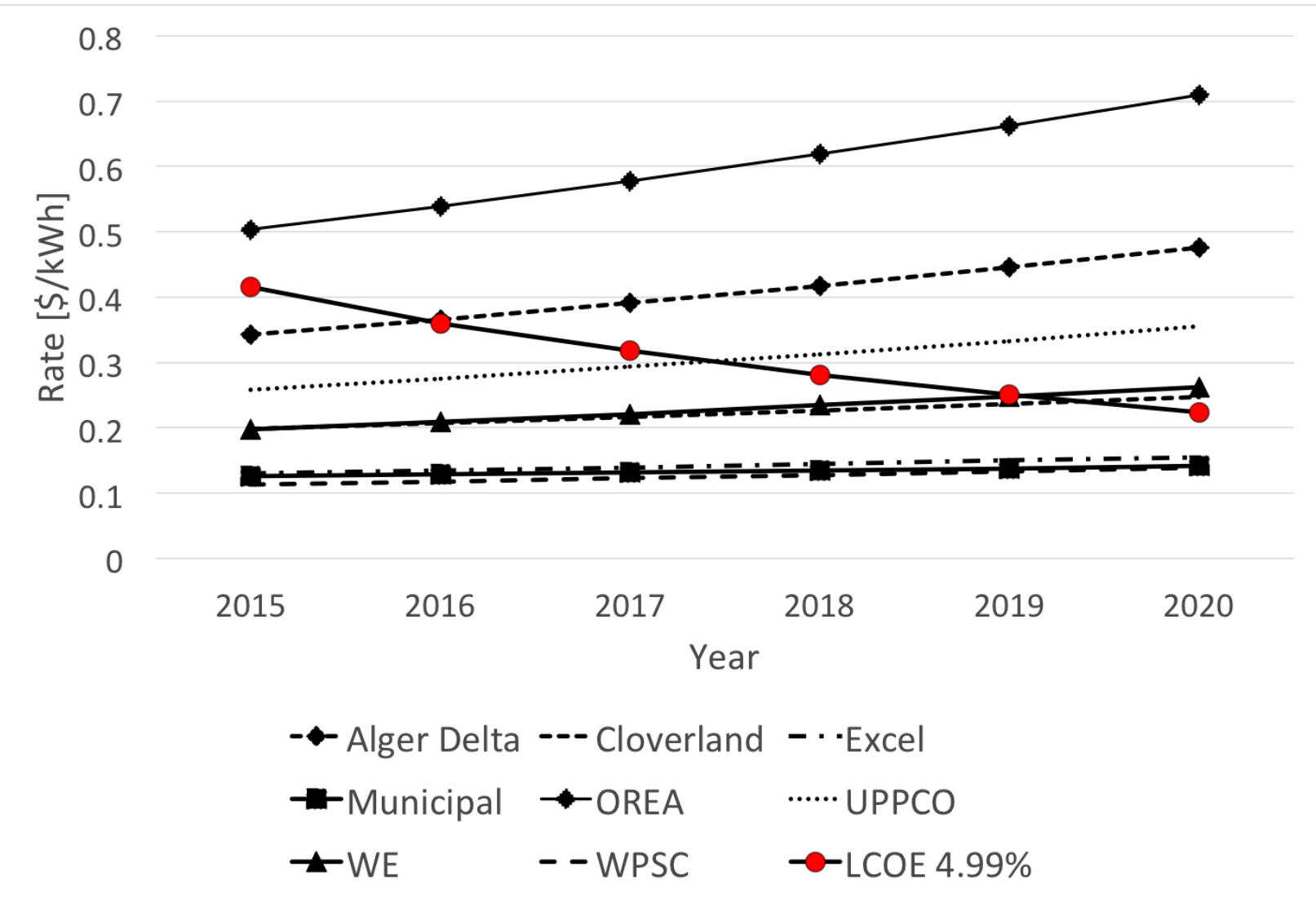

Figure 2a: Grid Parity Model Results for Seasonal Households in the UP by Utility, 2015-2020 
Preprint: Abhilash Kantamneni, Richelle Winkler, Lucia Gauchia, Joshua M. Pearce, Emerging economic viability of grid defection in a northern climate using solar hybrid systems. Energy Policy 95, 378-389 (2016). doi: 10.1016/j.enpol.2016.05.013

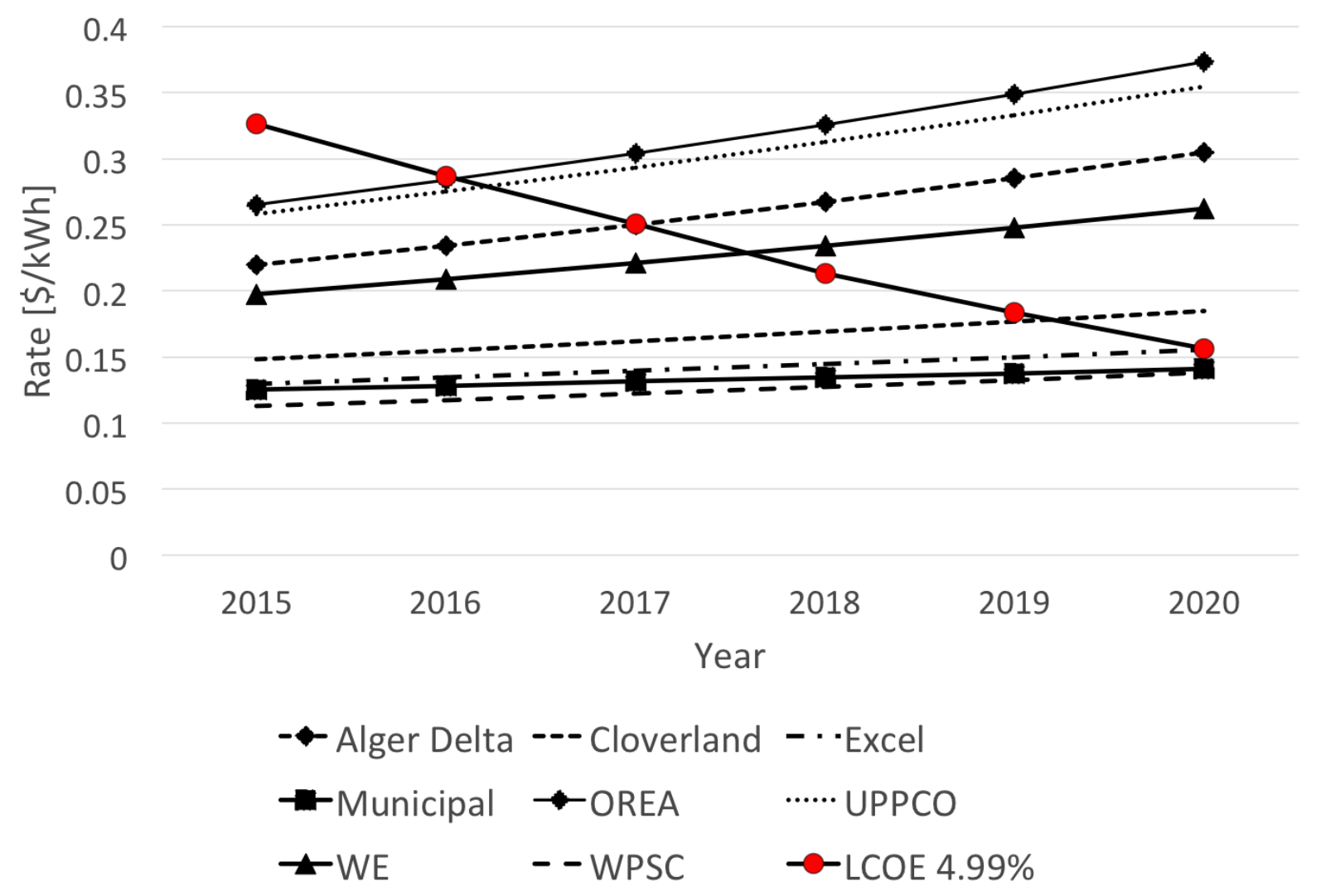

Figure 2b: Grid Parity Model Results for Year-Round Households in the UP by Utility, 2015-2020 Projected utility rates are shown in the vertical axis and are projected to rise over time, assuming recent historical rate increases continue. The LCOE (shown with red dots) for the solar hybrid system is projected to decline over the next five years. Utilities with a point above the LCOE have reached grid parity. 
Preprint: Abhilash Kantamneni, Richelle Winkler, Lucia Gauchia, Joshua M. Pearce, Emerging economic viability of grid defection in a northern climate using solar hybrid systems. Energy Policy 95, 378-389 (2016). doi: 10.1016/j.enpol.2016.05.013

\section{Tables}

Table 1: Number of customers and annual utility charges for UP utilities (2013)

\begin{tabular}{ccccc}
\hline Utility & Total Customers & Service Charge/year & Energy Charge & Effective Rate \\
& & {$[\$]$} & {$[\$ / \mathrm{kWh}]$} & {$[\$ / \mathrm{kWh}]$} \\
\hline Alger Delta & 9,458 & 300 & 0.1490 & 0.2108 \\
Cloverland & 35,775 & 108 & 0.1154 & 0.1375 \\
Excel & 7,750 & 99 & 0.0863 & 0.1205 \\
Municipal & $26,708^{*}$ & $\mathrm{n} / \mathrm{a}$ & $\mathrm{n} / \mathrm{a}$ & 0.1195 \\
OCREA & 4,509 & 240 & 0.1870 & 0.2433 \\
UPPCO & 46,206 & 144 & 0.1961 & 0.2273 \\
WE & 24,456 & 209 & 0.1377 & 0.1762 \\
WPSC & 8,007 & 108 & 0.0849 & 0.1041 \\
\hline
\end{tabular}

* Municipal customer numbers are not available and so estimated based off total population living in municipalities with a municipally owned utility and observed ratio of population to utility customers across the UP.

Source: Annual Reports of Utilities (2013) as provided by the Michigan Public Service Commission. Effective rate includes state mandated Energy Optimization surcharge (EO) and individual utility Power Supply Cost Recovery Factor (PSCR) as well as service and energy charges. 
Preprint: Abhilash Kantamneni, Richelle Winkler, Lucia Gauchia, Joshua M. Pearce, Emerging economic viability of grid defection in a northern climate using solar hybrid systems. Energy Policy 95, 378-389 (2016). doi: 10.1016/j.enpol.2016.05.013

Table 2: Annual electricity consumption (kWh) by household class and service area

\begin{tabular}{ccccccccc}
\hline & & \multicolumn{7}{c}{ Household Type } \\
Utility & $\begin{array}{c}\text { Season } \\
\text { al }\end{array}$ & Total & $\mathbf{1 p H H}$ & $\begin{array}{c}\mathbf{2} \mathbf{p H} \\
\mathbf{H}\end{array}$ & $\mathbf{3 p H H}$ & $\mathbf{4 p H H}$ & $\mathbf{5 p H H}$ & $\mathbf{6 p H H}$ \\
\hline $\begin{array}{c}\text { Alger } \\
\text { Delta }\end{array}$ & 2,013 & 7,351 & 4,383 & 6,782 & 7,351 & 8,567 & 8,807 & 9,464 \\
$\begin{array}{c}\text { Cloverlan } \\
\text { d }\end{array}$ & 2,595 & 9,319 & 5,556 & 8,597 & 9,319 & 10,860 & 11,165 & 11,997 \\
Excel & 2,304 & 8,335 & 4,969 & 7,689 & 8,335 & 9,713 & 9,986 & 10,731 \\
Municipal & 2,304 & 8,335 & 4,969 & 7,689 & 8,335 & 9,713 & 9,986 & 10,731 \\
OCREA & 2,304 & 8,335 & 4,969 & 7,689 & 8,335 & 9,713 & 9,986 & 10,731 \\
UPPCO & 2,304 & 8,335 & 4,969 & 7,689 & 8,335 & 9,713 & 9,986 & 10,731 \\
WE & 2,304 & 8,335 & 4,969 & 7,689 & 8,335 & 9,713 & 9,986 & 10,731 \\
WPSC & 2,304 & 8,335 & 4,969 & 7,689 & 8,335 & 9,713 & 9,986 & 10,731 \\
\hline
\end{tabular}

Source: Author-generated estimates based off utility-reported consumption (Annual Reports of Utilities 2013, available from the Michigan Public Service Commission) on seasonal and yearround consumption by utility and RECS data on average energy consumption by household size for cold/very cold regions (EIA 2009). 
Preprint: Abhilash Kantamneni, Richelle Winkler, Lucia Gauchia, Joshua M. Pearce, Emerging economic viability of grid defection in a northern climate using solar hybrid systems. Energy Policy 95, 378-389 (2016). doi: 10.1016/j.enpol.2016.05.013

Table 3. Model assumptions for capital, fuel and operating costs of the hybrid systems and utility rates

\begin{tabular}{cccccccc}
\hline Year & $\begin{array}{c}\text { Storage } \\
{[\mathbf{\$} / \mathbf{k W h}]}\end{array}$ & $\begin{array}{c}\mathbf{P V} \\
{[\mathbf{\$} / \mathbf{k W}]}\end{array}$ & $\begin{array}{c}\mathbf{C H P} \\
{[\mathbf{\$} / \mathbf{k W e}]}\end{array}$ & $\begin{array}{c}\text { Natural Gas } \\
{[\mathbf{\$} / \mathbf{T h e r m}]}\end{array}$ & $\begin{array}{c}\text { CHP } \\
\text { Operation } \\
{[\mathbf{\$} / \mathbf{k W h}]}\end{array}$ & $\begin{array}{c}\text { Range of Effective Utility } \\
\text { Rates [\$/kWh] }\end{array}$ \\
\hline 2015 & 621.00 & 3.50 & 1400.00 & 0.90 & 0.08 & $.11-.27$ & $.11-.50$ \\
2016 & 506.89 & 2.95 & 1400.00 & 0.92 & 0.08 & $.12-.28$ & $.12-.54$ \\
2017 & 413.74 & 2.49 & 1400.00 & 0.94 & 0.08 & $.12-.30$ & $.12-.58$ \\
2018 & 337.71 & 2.11 & 1400.00 & 0.96 & 0.08 & $.13-.33$ & $.13-.62$ \\
2019 & 275.65 & 1.78 & 1400.00 & 0.97 & 0.09 & $.13-.35$ & $.13-.66$ \\
2020 & 225.00 & 1.50 & 1400.00 & 0.99 & 0.09 & $.14-.37$ & $.14-.71$ \\
\hline
\end{tabular}

Source: Author-generated extrapolations of future costs based on current observed costs and recent historical trends. 
Table 4: Solar-Hybrid System Design by Household Type and Estimated Costs

\begin{tabular}{|c|c|c|c|c|c|c|c|c|c|c|c|c|c|c|}
\hline \multirow[t]{2}{*}{$\begin{array}{l}\text { Househol } \\
\text { d Type }\end{array}$} & \multirow[t]{2}{*}{$\begin{array}{c}\text { Annual } \\
\text { Consumption } \\
{[\mathrm{kWh}]}\end{array}$} & \multirow[t]{2}{*}{$\begin{array}{c}\text { PV size } \\
{[\mathrm{kW}]}\end{array}$} & \multirow[t]{2}{*}{$\begin{array}{c}\text { Storage }^{1} \\
\text { size } \\
{[\mathbf{k W h}]}\end{array}$} & \multirow[t]{2}{*}{$\begin{array}{c}\text { Generator }^{1} \\
\text { size }[k W]\end{array}$} & \multicolumn{2}{|c|}{$\begin{array}{c}\text { Installment Costs }{ }^{4} \\
{[\$]}\end{array}$} & \multicolumn{2}{|c|}{$\begin{array}{c}\text { Down Payment }^{2} \\
{[\$]}\end{array}$} & \multicolumn{2}{|c|}{$\begin{array}{c}\text { Yearly Finance } \\
\text { Repayment Cost } \\
\text { [\$/year] }\end{array}$} & \multicolumn{2}{|c|}{$\begin{array}{c}\text { Annual Costs } \\
\text { [\$/year] }\end{array}$} & \multicolumn{2}{|c|}{ LCOE $[\$ / k W h]$} \\
\hline & & & & & 2015 & 2020 & 2015 & 2020 & 2015 & 2020 & 2015 & 2020 & 2015 & 2020 \\
\hline Seasonal & 2,304 & 1.66 & 3.2 & $0 *$ & $\$ 9,174$ & $\$ 4,602$ & $\$ 0$ & $\$ 0$ & $\$ 459$ & $\$ 230$ & $\$ 0$ & $\$ 0$ & $\$ 0.42$ & $\$ 0.22$ \\
\hline $1 \mathrm{pHH}$ & 4,969 & 3.58 & 6.8 & 1 & $\$ 18,167$ & $\$ 8,306$ & $\$ 0$ & $\$ 0$ & $\$ 908$ & $\$ 415$ & $\$ 311$ & $\$ 311$ & $\$ 0.37$ & $\$ 0.17$ \\
\hline $2 \mathrm{pHH}$ & 7,689 & 5.54 & 10.5 & 1 & $\$ 27,344$ & $\$ 12,085$ & $\$ 0$ & $\$ 0$ & $\$ 1,367$ & $\$ 604$ & $\$ 438$ & $\$ 438$ & $\$ 0.33$ & $\$ 0.16$ \\
\hline 3pHH & 8,335 & 6.01 & 11.4 & 1 & $\$ 29,523$ & $\$ 12,983$ & $\$ 0$ & $\$ 0$ & $\$ 1,476$ & $\$ 649$ & $\$ 468$ & $\$ 468$ & $\$ 0.33$ & $\$ 0.16$ \\
\hline $4 \mathrm{pHH}$ & 9,713 & 7.00 & 13.3 & 1 & $\$ 34,173$ & $\$ 14,898$ & $\$ 4,173$ & $\$ 0$ & $\$ 1,500$ & $\$ 745$ & $\$ 532$ & $\$ 532$ & $\$ 0.31$ & $\$ 0.15$ \\
\hline $5 \mathrm{pHH}$ & 9,986 & 7.20 & 13.7 & 1 & $\$ 35,094$ & $\$ 15,277$ & $\$ 5,094$ & $\$ 0$ & $\$ 1,500$ & $\$ 764$ & $\$ 544$ & $\$ 544$ & $\$ 0.31$ & $\$ 0.15$ \\
\hline 6рHН & 10,731 & 7.74 & 14.7 & 1 & $\$ 37,607$ & $\$ 16,312$ & $\$ 7,607$ & $\$ 0$ & $\$ 1,500$ & $\$ 816$ & $\$ 579$ & $\$ 579$ & $\$ 0.30$ & $\$ 0.15$ \\
\hline
\end{tabular}

* Seasonal customers do not use generator backup

${ }^{1}$ Replaced after 15 years, replacement costs included in LCOE

${ }^{2}$ Down payments are required for system costs $>\$ 30,000$ (Michigan Saves, 2015)

${ }^{3}$ Operation, fuel costs, oil changes and other maintenance

${ }^{4}$ Calculated from Table 3 Projections 
Table 5: Projected home-owners reaching grid parity and affording to finance a solar-hybrid system

\begin{tabular}{rrrrr}
\hline Year & $\begin{array}{r}\text { Single Family Households Reaching Grid Parity } \\
\text { Seasonal }\end{array}$ & $\begin{array}{r}\text { Year-Round } \\
\text { Total }\end{array}$ & $\begin{array}{c}\text { Total Achieving } \\
\text { Grid Parity and } \\
\text { with Economic } \\
\text { Means 1,970 }\end{array}$ \\
2015 & 1,970 & 0 & 1,970 & 6,391 \\
2016 & 5,732 & 1,465 & 7,197 & 29,520 \\
2017 & 5,732 & 34,714 & 40,446 & 50,673 \\
2018 & 16,420 & 51,261 & 67,681 & 51,627 \\
2019 & 16,420 & 52,558 & 68,978 & 85,368 \\
\hline 2020 & 37,843 & 69,998 & 107,841 & \\
\hline
\end{tabular}

Source: Author calculations of the number of single-family owner-occupied households in Michigan's Upper Peninsula for whom a solar-hybrid system would reach grid parity and whom would qualify for loan and could afford to finance a solar-hybrid system at $4.99 \%$ interest rate. 
Table 6: Projected proportion of home-owners reaching grid parity and affording system

\begin{tabular}{|c|c|c|c|c|}
\hline \multirow[b]{2}{*}{ Year } & \multicolumn{3}{|c|}{ Single Family Households Reaching Grid Parity } & \multirow{2}{*}{$\begin{array}{c}\text { Total Achieving } \\
\text { Grid Parity and } \\
\text { with Economic } \\
\text { Means }\end{array}$} \\
\hline & Seasonal & Year-Round & Total & \\
\hline 2015 & $4.8 \%$ & $0 \%$ & $1.5 \%$ & $1.5 \%$ \\
\hline 2016 & $14.0 \%$ & $1.6 \%$ & $5.4 \%$ & $4.8 \%$ \\
\hline 2017 & $14.0 \%$ & $38.0 \%$ & $30.6 \%$ & $22.3 \%$ \\
\hline 2018 & $40.1 \%$ & $56.1 \%$ & $51.1 \%$ & $38.3 \%$ \\
\hline 2019 & $40.1 \%$ & $57.5 \%$ & $52.1 \%$ & $39.0 \%$ \\
\hline 2020 & $92.4 \%$ & $76.6 \%$ & $81.5 \%$ & $64.5 \%$ \\
\hline
\end{tabular}

Source: Author calculations of the proportion of single-family owner-occupied households in Michigan's Upper Peninsula for whom a solar-hybrid system would reach grid parity and whom would qualify for loan and could afford to finance a solar-hybrid system at $4.99 \%$ interest rate. 